\title{
Crustaceans from a tropical estuarine sand-mud flat, Pacific, Costa Rica, (1984-1988) revisited
}

\author{
José A. Vargas-Zamora ${ }^{1,2}$, Jeffrey A. Sibaja-Cordero ${ }^{1,2} \&$ Rita Vargas-Castillo ${ }^{3}$ \\ 1. Centro de Investigación en Ciencias del Mar y Limnología (CIMAR), Universidad de Costa Rica, 11501-2060, San \\ José, Costa Rica. javargasz@biologia.ucr.ac.cr \\ 2. Escuela de Biología, Universidad de Costa Rica, 11501-2060, San José, Costa Rica; jeffro.alejandro@gmail.com \\ 3. Museo de Zoología, Escuela de Biología. Universidad de Costa Rica, 11501-2060, San José, Costa Rica; \\ rita.vargas@ucr.ac.cr
}

Received 27-II-2012. C Corrected 04-V-2012. Accepted 20-VI-2012.

\begin{abstract}
The availability of data sets for time periods of more than a year is scarce for tropical environments. Advances in hardware and software speed-up the re-analysis of old data sets and facilitates the description of population oscillations. Using recent taxonomic literature and software we have updated and re-analized the information on crustacean diversity and population fluctuations from a set of cores collected at a mud-sand flat in the mid upper Gulf of Nicoya estuary, Pacific coast of Costa Rica (1984-1988). A total of 112 morphological species of macroinvertebrates was found, of which 29 were crustaceans. Taxonomic problems, maily with the peracarids, prevented the identification of a group of species. The abundance patterns of the crab Pinnixa valerii, the ostracod Cyprideis pacifica, and the cumacean Coricuma nicoyensis were analized with the Generalized Additive Models of the free software $R$. The models evidenced a variety of population oscillations during the sampling period. These oscillations probably included perturbations induced by external factors, like the strong red tide events of 1985. In additon, early on 1984 the populations might have been at an altered state due to the inpact of El Niño 1982-83. Thus, the oscillations observed during the study period departed from the expected seasonality (dry $v s$ rainy) pattern and are thus considered atypical for this tropical estuarine tidal-flat. Crustacean diversity and population peaks were within the range of examples found in worldwide literature. However, abundances of the cumacean $C$. nicoyensis, an endemic species, are the highest reported for a tropical estuary. Comparative data from tropical tidal flat crustaceans continues to be scarce. Crustaceans (total vs groups) had population changes in response to the deployment of predator exclusion cages during the dry and rainy seasons of 1985. Temporal and spatial patchiness characterized the abundances of P. valeri, C. pacifica and C. nicoyenis. Rev. Biol. Trop. 60 (3): 1763-1781. Epub 2012 September 01.
\end{abstract}

Key words: Crustacea, Coricuma, Cyprideis, Pinnixa, benthos, caging, estuary, tidal flat, Gulf of Nicoya, Costa Rica.

From 1979 to 1983 ecological surveys were conducted in the Gulf of Nicoya estuary to provide baseline information in support of management policies (see references in Vargas $\&$ Mata 2004). These studies were followed by a three year study (1984-1987) of an intertidal site in the mid upper estuary. The study included the deployment of predator exclusion cages in 1985 (Vargas 1987, 1988, 1989a, 1996). Since these papers were published the identification of the marine biodiversity of Costa
Rica made significant advances summarized by Wehrtmann \& Cortés (2009). In addition, advances in hardware and software during the last decades have allowed the re-analysis of the original data set to explore the identification of hidden data patterns. The application of the Generalized Additive Models (GAM) to several of the molluscan species collected was conducted by Vargas-Zamora \& SibajaCordero (2011). Thus, the objective of this study is to make accesible an updated list of the 
crustacean species found at the sand-mud flat during 1984-1987 and neighboor biotopes, and to apply the GAM methodology to the abundances of three species: the pinnotherid crab Pinnixa valerii, the ostracod Cyprideis pacifica and the cumacean Coricuma nicoyensis.

\section{MATERIALS \& METHODS}

The survey methods have been described in detail by Vargas (1987). In summary: cores (core area $17.7 \mathrm{~cm}^{2}, 15 \mathrm{~cm}$ deep) were collected from February, 1984 to April, 1987 (49 dates) at an intertidal (tidal range: $3 \mathrm{~m}$ ) mud-sand 20x20m plot in the mid upper Gulf of Nicoya estuary, Pacific, Costa Rica (Fig. 1). From February 1984 to February 1985 semi-monthly sampling (two sets of 14 cores per date) was conducted at 12 to 18 day intervals ( 25 dates), with monthly sampling afterwads (24 dates, two sets of 7 cores per date). Each set was collected at different locations within the plot. To further study population fluctuations of the cumacean $C$. nicoyensis, additional samples (two sets of 7 cores per date) were collected at monthly intervals from April 29, 1987 until July 4, 1988 (26 dates), for a total of 75 sampling trips (Vargas 1989b).

The species lists included in Vargas (1987, 1988) was updated using Wehrtmann \& Cortés (2009) and on the web with w.w.w.WORMS (World Register of Marine Species). Temporal trends were analyzed for the top three numerically abundant (in 14 cores) identified species of crustaceans ( $P$. valerii, C. pacifica, and $C$. nicoyensis) with the Generalized Additive Model (GAM) of the free mgcv package in The $R$ Project for Statistical Computing, with abundances $\log _{10}(\mathrm{x}+1)$ transformed to homogenize variances (Collie et al. 2000, Stoner et al. 2001, Wood 2006). The GAM was carried out with the subroutine quasi (Wood 2006).

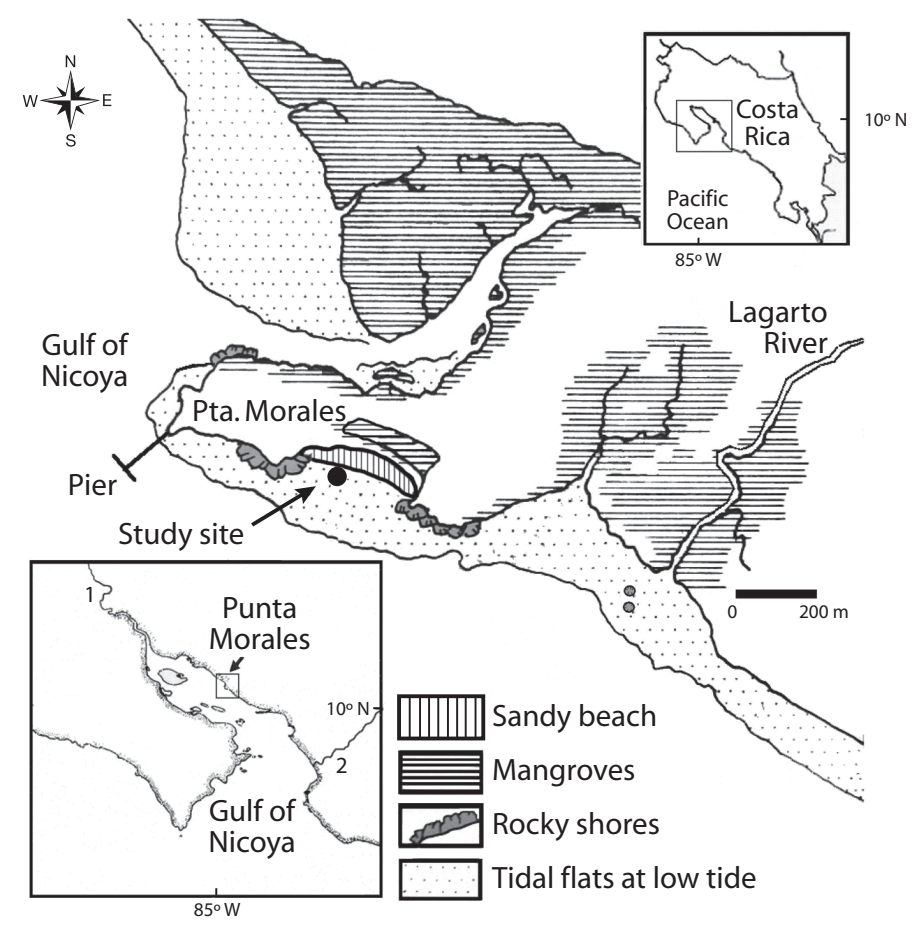

Fig. 1. Location of the study site at the Punta Morales peninsula, Gulf of Nicoya estuary $\left(10^{\circ} 04^{\prime} \mathrm{N}-84^{\circ} 58^{\prime} \mathrm{W}\right)$, Pacific coast of Costa Rica. 1: Tempisque river. 2: Tárcoles river. 
For the first year of data we used the first of the two sets of 14 cores collected per date as input for the GAM. The mean abundances per season (with 95\% confidence limits) of the three species were computed also with $\log _{10}(\mathrm{x}+1)$ transformed data and back to the original scale for graphical display. To illustrate spatial variability in the abundances of $P$. valerii, C. pacifica and C. nicoyensis, the Morisita index of dispersion (Colby \& Fonseca 1984) was computed for the date with the higest number of individuals of each species. Cages $(0.5 \times 0.5 \times 0.2 \mathrm{~m}$, galvanized wire, $5 \mathrm{~mm}$ mesh) to exclude macropredators were deployed by Vargas (1988) during the dry and rainy seasons of 1985 . Crustacean abundances inside and outside cages were compared with a paired $t$-test on $\log _{10}(\mathrm{x}+1)$ transformed data. A Chi-square $\left(\chi^{2}\right)$ test was used to compare the total number of individuals and of species inside and outside cages.

\section{RESULTS}

\section{Uncaged sediments}

Information on environmental data is included in Vargas (1987, 1988, 1989a), Vargas \& Solano (2011), and Vargas-Zamora \& SibajaCordero (2011). In summary: sediment composition was on the average $65 \%$ sand and $32 \%$ silt+clay. Water salinity ranged from $22 \%$ (rainy season) to $34 \%$ (dry season). Seasonal trends in sediment and water temperatures were not reported by Vargas (1987, 1988). Water temperatures above $30^{\circ} \mathrm{C}$ were the norm, with a maximum of $40^{\circ} \mathrm{C}$ on April 1984 (Vargas 1987). The estuarine water flows of the Gulf of Nicoya have been described by Voorhis et al. (1983), which are driven mainly by seasonal input of freshwater (dry season: DecemberApril; rainy season: May-November).

The updated macrofaunal list included 112 species (Table 1) of macroinvertebrates (= retained on a 500 micron sieve) of which 29 were crustaceans (Table 1): 16 decapods, four amphipods, two cumaceans, two ostracods, two stomatopods, and one each of penaeid shrimps, mysids and tanaidaceans. In addition, other species of crustaceans reported for the site near the time of the survey, and deposited in the collections of the Museum of Zoology of the University of Costa Rica, are also included in table 1.

Abundances found at sem[i-monthly intervals during the first year ( 25 dates, $1^{\text {st }}$ set of 14 cores), and at montly intervals afterwards were included in Figs. 2, 3 and 4, for P. valerii, $C$. pacifica and $C$. nicoyensis, respectively. These species were characterized by population fluctuations of different magnitude during the sampling period.

The application of a GAModel to the abundances of the crab P. valerii resulted (Fig. 5A) in three peaks of abundance that do not coincide with periods of either the rainy or the dry seasons during the three year study. However, peaks appear to decline shortly after the onset of the transition between seasons $(\mathrm{F}=17.80$, $\mathrm{p}<0.001$, Fig. 5A,B). When the pooled abundances per season were compared, no significant difference between seasons was detected $(\mathrm{t}=-1.08, \mathrm{p}=0.285$, Fig. 5C).

The GAModel applied to the abundances of the ostracod C. pacifica also evidenced (Fig. 5D) no seasonal peaks, but a declining population over the three year survey $(\mathrm{F}=19.13$, $\mathrm{p}$ $<0.001)$. However, in 1984-85 there were higher abundances during the dry seasons, while in 1986-87 lower abundances characterized these seasons (Fig. 5D,E). When pooled abundances per season were compared, no significant difference between seasons was detected $(\mathrm{t}=-0.50$, $\mathrm{p}=0.619$, Fig. $5 \mathrm{~F}$ ).

The abundance data (75 dates) for the cumacean C. nicoyensis presented in Fig. 4 showed more frequent peaks during the dry seasons, with higher values during the dry seasons of 1984, 1985, and 1988, but not as evident as during the dry season of 1986-1987. The application of a GAModel confirmed this oscillation in time $(\mathrm{F}=12.78, \mathrm{p}<0.001$, Fig. $6 \mathrm{~A}, \mathrm{~B})$. The abundance of this species declined from 1984 until mid 1987, when the population began a recovery $(\mathrm{F}=7.89, \mathrm{p}<0.001$, Fig. $6 \mathrm{~B})$. Moreover, when pooled abundances per season were compared, a highly significant difference 
TABLE 1

List of 29 crustaceans collected by coring at a $400 \mathrm{~m}^{2}$ plot at the Punta Morales intertidal sand-mud flat. Gulf of

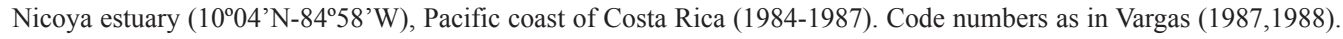
$\mathrm{M}=$ Malacostraca, $\mathrm{O}=$ Ostracoda. $\mathrm{N}=$ total number of individuals collected

\begin{tabular}{|c|c|c|c|c|c|}
\hline Code & Class & Order & Family & Species & $\mathrm{N}$ \\
\hline 38 & M & Cumacea & Leuconidae & Coricuma nicoyensis Watling \& Breedy, 1988 & 4435 \\
\hline 34 & $\mathrm{O}$ & Podocopida & Cytherideidae & Cyprideis pacifica Hartmann, 1957. & 4037 \\
\hline 33 & M & Decapoda & Pinnotheridae & Pinnixa valerii Rathbun, 1931. & 362 \\
\hline 66 & M & Decapoda & Pinnotheridae & Pinnotheridae indet.* & 198 \\
\hline 35 & $\mathrm{O}$ & Podocopida & & Podocopida indet. & 98 \\
\hline 86 & M & Decapoda & Panopeidae & Panopeus spp**. & 86 \\
\hline 44 & M & Amphipoda & & Amphipoda, Gammaridea indet. $1 * * *$ & 47 \\
\hline 74 & M & Amphipoda & & Amphipoda, Gammaridea indet. 2 & 47 \\
\hline 79 & M & Amphipoda & & Amphipoda, Gammaridea indet. 3 & 44 \\
\hline 37 & M & Amphipoda & Corophiidae & Corophium sp. & 42 \\
\hline 39 & M & Decapoda & Alpheidae & Alpheus mazatlanicus Wicksten, 1983 & 41 \\
\hline 43 & M & Decapoda & Penaeidae & Trachypenaeus byrdi (Burkenroad, 1934) & 30 \\
\hline 76 & M & Cumacea & & Cumacea indet. $* * * *$ & 27 \\
\hline 31 & M & Decapoda & Portunidae & Callinectes arcuatus Ordway, 1863 & 24 \\
\hline 80 & M & Decapoda & Porcellanidae & Porcellanidae indet. & 12 \\
\hline 67 & M & Decapoda & Diogenidae & Clibanarius lineatus (H. Milne Edwards, 1848) & 11 \\
\hline 97 & M & Decapoda & Leucosiidae & Leucosilia jurinii (Saussure, 1853) & 9 \\
\hline 41 & M & Decapoda & Panopeidae & Prionoplax ciliata Smith, 1870 & 8 \\
\hline 32 & M & Decapoda & Pinnotheridae & Pinnixa sp. & 7 \\
\hline 96 & M & Decapoda & Callianassidae & Lepidophthalmus bocourti (A.Milne-Edwards, 1870) & 7 \\
\hline 42 & M & Tanaidacea & Apseudidae & Apseudes sp.***** & 6 \\
\hline 73 & M & Decapoda & Leucosiidae & Iliacantha hancocki Rathbun, 1935 & 6 \\
\hline 36 & M & Stomatopoda & Gonodactylidae & Neogonodactylus festae (Nobili, 1901) & 4 \\
\hline 113 & M & Decapoda & Penaeidae & Lithopenaeus occidentalis (Streets, 1871) & 4 \\
\hline 77 & M & Decapoda & Alpheidae & Alpheus sp. & 3 \\
\hline 98 & M & Mysida & & Mysida indet. $* * * * *$ & 3 \\
\hline 40 & M & Decapoda & Albuneidae & Albunea lucasia de Saussure, 1853 & 2 \\
\hline 89 & M & Stomatopoda & Squillidae & Squilla aculeata Bigelow, 1893 & 1 \\
\hline 93 & M & Decapoda & Leucosiidae & Persephona townsendi (Rathbun, 1894) & 1 \\
\hline
\end{tabular}

*: The Museum of Zoology of the University of Costa Rica has in its collections the following macro-crustaceans (in alphabethical order) collected in sand / mud-sand (S), and rocky (sandstone) outcrops (R) around the study site in Punta Morales: Acantholobulus bermudensis (S,R), A. miraflorescensis (S,R), Acantholobulus sp. (S,R), Alpheus hamus (S), Alpheus sp. (S), A. tenuis (S,R), Austinotheres sp. (S), Clibanarius albidigitus (S,R), Coenobita compressus $(\mathrm{R}, \mathrm{S})$, Cloridopsis dubia (S), Cyrtoplax schmitti (S), Eurypanopeus canalensis (R,S), E. planus (R,S), E. transversus (R,S), Eurytium tristani (R,S), Megalobrachium erosum (R), Notolopas lamellatus (S), Pachycheles panamensis (R), P. spinidactylus (R), Pachygrapsus transversus (R), Petrolisthes armatus (R), Salmoneus sp. (S), Synalpheus sanjosei (S), Synalpheus sp. (S), Uca beebei (S), U. herradurensis (S), U. inaequalis (S), U. limicola (S), U. saltitanta (S), U. tomentosa (S), U. umbratila (S), Ucides occidentalis (S), Upogebia maccraryae (S), U. spinigera (S), U. vargasae (S), and Petrolisthes angelicus, a simbiont in the rocky oyster Saccostrea palmula.

**: There are two species of Panopeus in the study area: P. chilensis and P. purpureus, of similar size and color. P. purpureus has the first and second carapace teeth coalesced. P. chilensis has carapace teeth 2-5 strongly curved.

***: Between 1998 and 2001 nearly 10.000 specimens of gammaridean amphipods were collected at several Caribbean and Pacific sites, including Punta Morales. Preliminary taxonomic work on these samples indicate that there might be over 100 species in 22 families, with about 20 species already identified (Foster et al. 2009). This latest addition brings the total number of known gammarideans from the Pacific coast of Costa Rica to about 40 species, with the genus Ampelisca as the most speciose.

****: There are 18 especies of cumaceans reported for the Pacific coast of Costa Rica but only two from the Gulf of Nicoya: Coricuma nicoyensis (study site), and Cyclaspis breedyae from the bay of Caldera (Petrescu et al. 2009).

*****: The are only four tanaidaceans reported for the Pacific coast of Costa Rica, two of which are from deep waters (Heard et al. 2009). Mysids of the shallower waters of the Pacific coast of Central America, Panama, and Mexico are poorly known. There are only four species reported for the Pacific coast of Costa Rica (Price et al. 2009). 


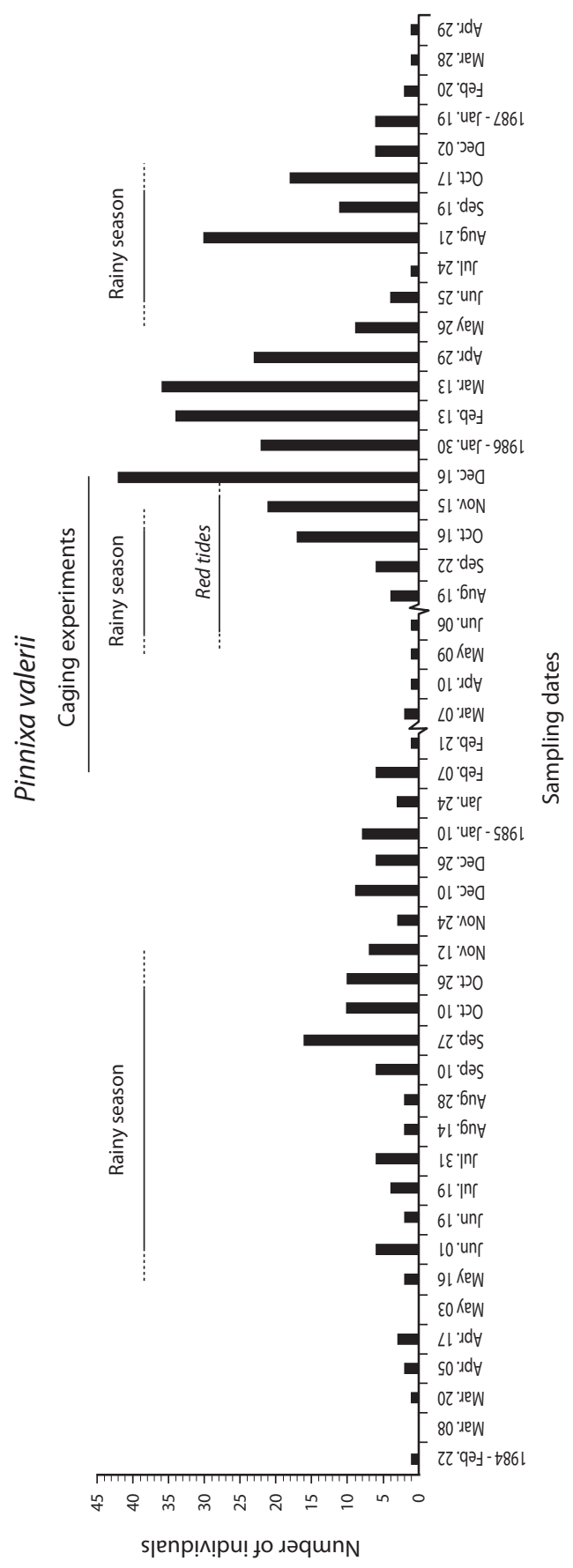

Fig. 2. Total number of individuals of the crab Pinnixa valerii found in 14 cores (total area $=0.025 \mathrm{~m}^{2}$ ) per date (49 dates) from February 22, 1984 to April 29, 1987. Punta Morales intertidal (tidal range: $3 \mathrm{~m}$ ) sand-mud flat, Gulf of Nicoya estuary $\left(10^{\circ} 04^{\prime} \mathrm{N}-84^{\circ} 58^{\prime} \mathrm{W}\right)$, Pacific coast of Costa Rica. $(\mathrm{t}=-3.76, \mathrm{p}<0.001$, Fig. 6 D) between seasons was detected.

The data on Figs 2, 3, 4 reveals a patchy distribution of the three species in time. Pachiness was also evident at the spatial scale. Differences were evident in the total abundances found in selected sets of 14 cores and collected at different positions and dates (Table 2). In addition, examples of the patchy abundance in individual cores are also included in table 2 .

\section{Caged sediments}

The total number of invertebrates was found significantly higher inside cages during the rainy season only (Table 3 ). Crustaceans as a group was more abundant outside cages during the rainy season (Table 3 ). Cumaceans were found significantly more abundant outside cages than inside, and the ostracods were significantly more abundant inside cages (Table 3). The crab P. valerii decreased its abundance inside cages during the rainy season $(\mathrm{t}=5.00, \mathrm{p}=0.002$, Fig. 7A). Total abundance of C. pacifica was higher inside cages than outside during the dry season (Fig. 7B), while the cumacean $C$. nicoyensis had the opposite trend (Fig. 7C). C. pacifica and C. nicoyensis had very low abundances outside and inside cages during the rainy season.

\section{DISCUSSION}

\section{The survey in perspective}

Information on environmental factors acting at different temporal and spatial scales is long overdue twenty five years after the survey of the sand-mud flat. Several of these factors were relevant in 1984-88 and continue to be relevant today: Core sampling at the sand-mud flat in the Gulf of Nicoya started in February 1984, shortly after Pacific coastal ecosystems were impacted by one of the stronger El Niño Southern Oscillation (ENSO) on record (19821983). This event altered global climatic patterns and raised water temperatures enough to cause severe coral mortalities on the Pacific 


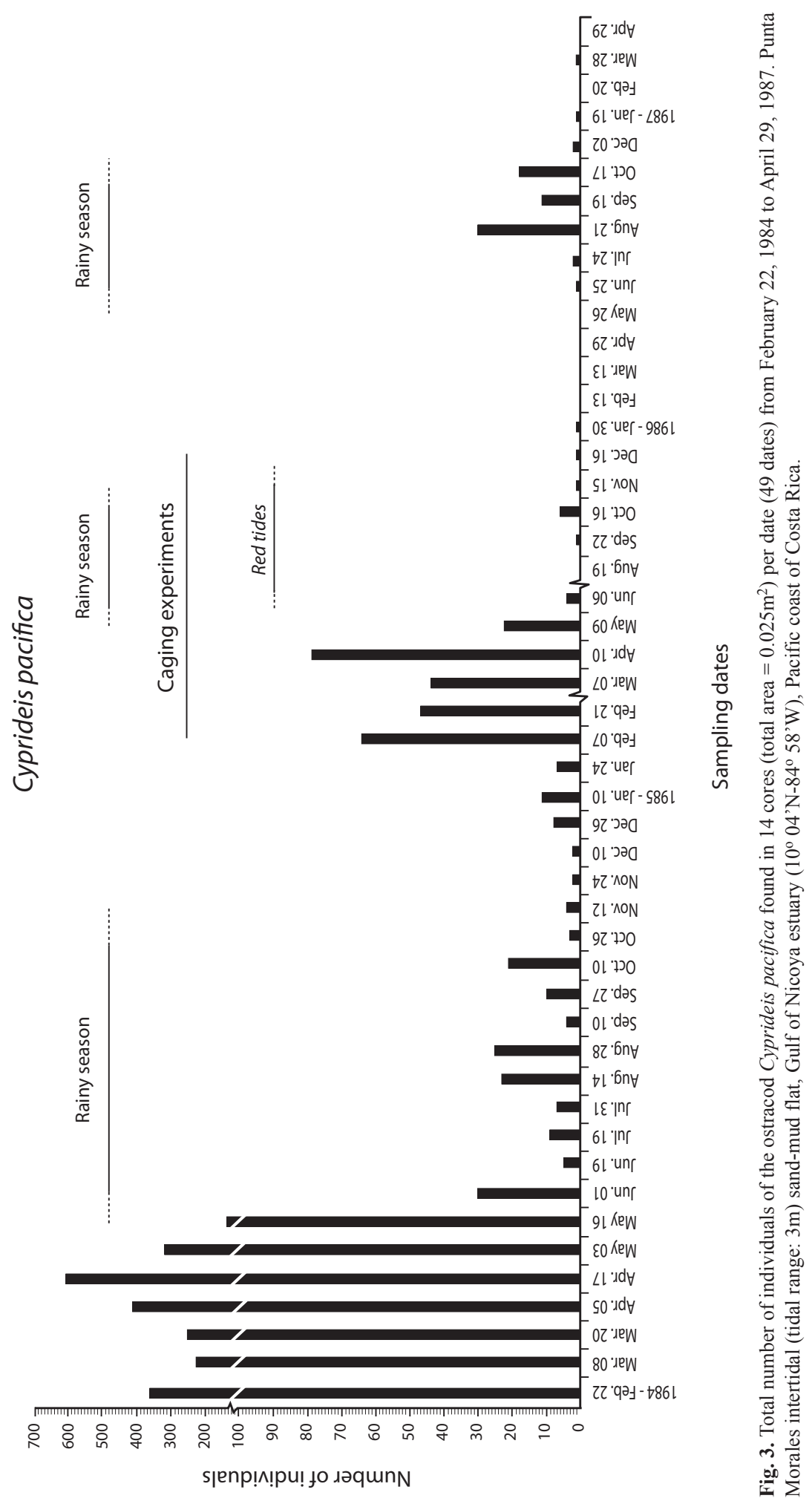




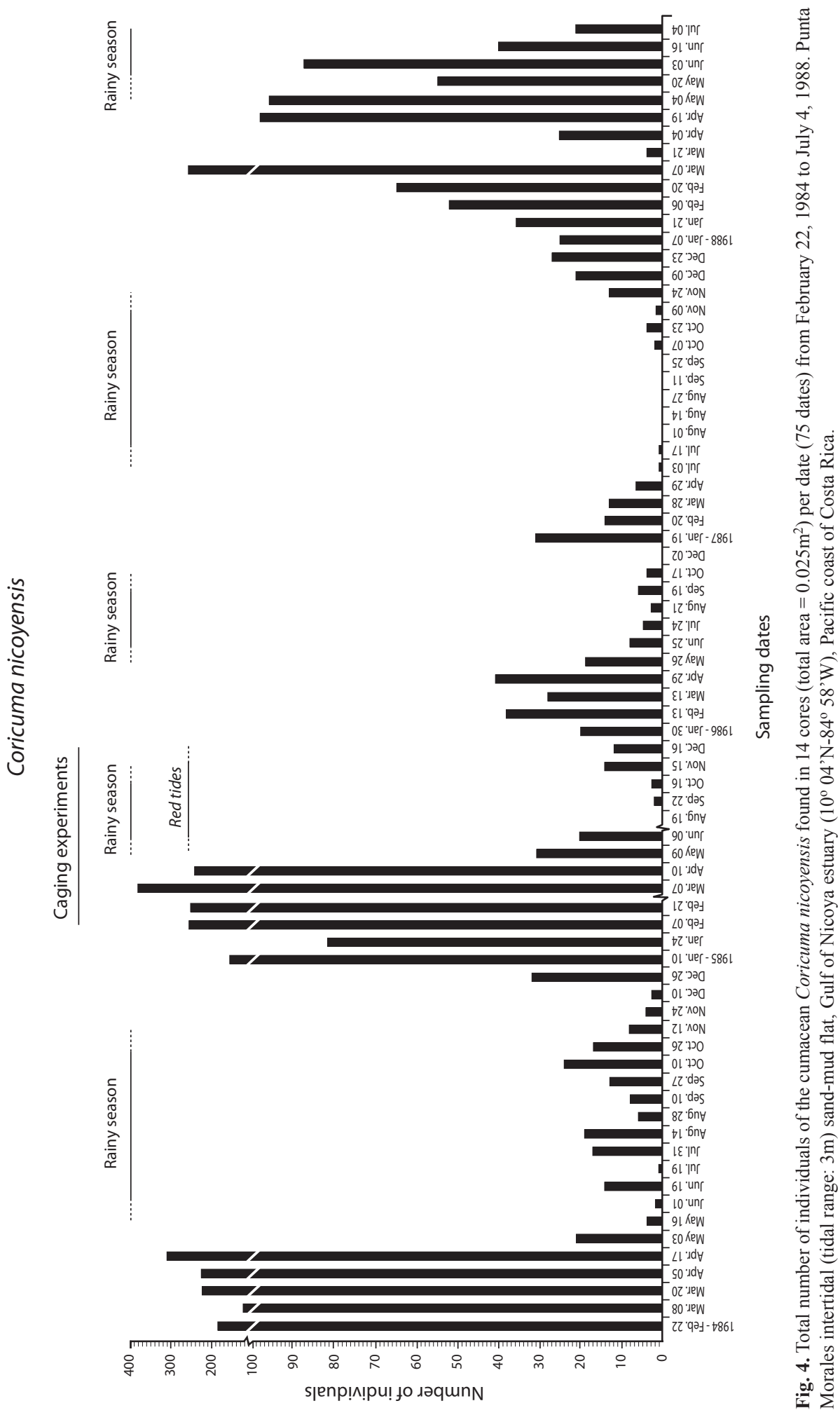


A Pinnixa valerii

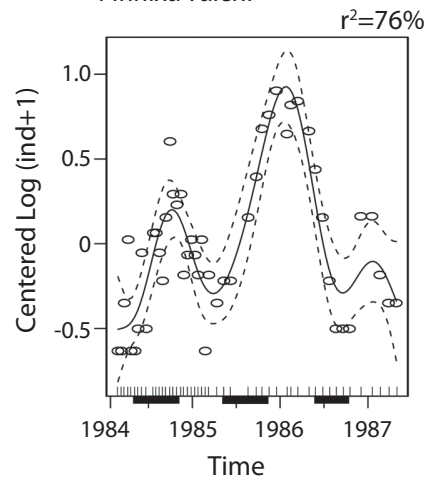

D Cyprideis pacifica $\quad r^{2}=76 \%$

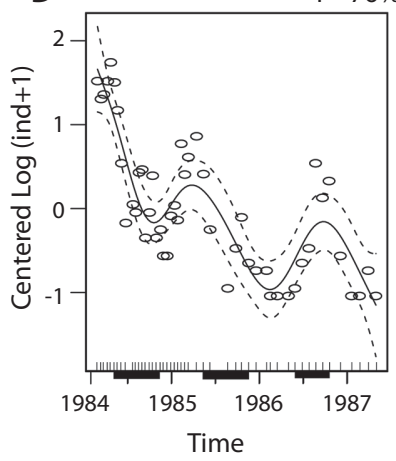

B

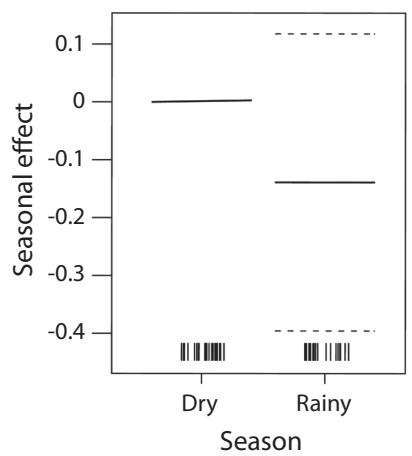

E

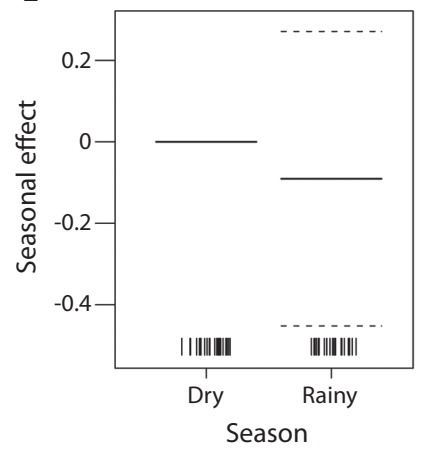

C

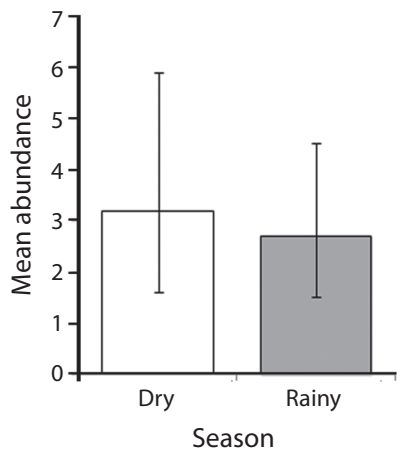

$\mathrm{F}$

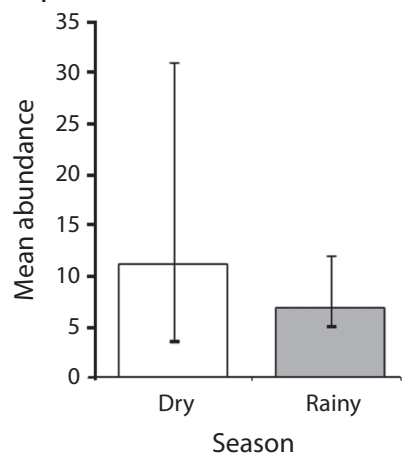

Fig. 5. A, B, D, E: Outputs of the Generalized Additive Models (GAM) for the abundances of: The crab Pinnixa valerii (A, B), and the ostracod Cyprideis pacifica (D, E). Solid lines are the fitted values for the models. Broken lines are the $95 \%$ confidence limits. Deviances explained were $76 \%$ in both cases. Dark bars at the bottom = rainy seasons. C, F. Seasonal (dry vs rainy) mean abundances for the 1984-1987 sampling period. Punta Morales sand-mud flat (1004'N-8458'W), Gulf of Nicoya estuary, Pacific, Costa Rica, 1984-1987.

coast of Costa Rica (Glynn et al. 1988). To what extent the intertidal macrofauna was at an altered state early in 1984 is not known. Drastic temperature oscillations caused by El Niño (warming) and La Niña (cooling) have produced important changes on the abundance and diversity of macrobenthos of intertidal and subtidal environments in Pacific Colombia and Ecuador (Tarazona et al. 1988, Vanagt et al. 2006). Was the ostracod Cyprideis pacifica taking advantage of El Niño and declined when it dissapeared remains a possibility.

The most conspicuous local environmental disturbance that may have altered the macrobenthos of the sand-mud flat was the series of algal blooms in the upper Gulf of Nicoya during 1985 caused by toxic and nontoxic diatoms and dinoflagellates. Dense patches were observed near the study site between April and November (Víquez \& Hargraves 1995). With the exception of a few gaping Tellina sp., clams found on the sediment surface on August, 1985 (Vargas-Zamora \& SibajaCordero 2011), other visible signs of the impact of these blooms on the benthos went unnoticed. In addition, data were not collected during July 1985. High mortality of the macrobenthos due mostly to anaerobic conditions following a 

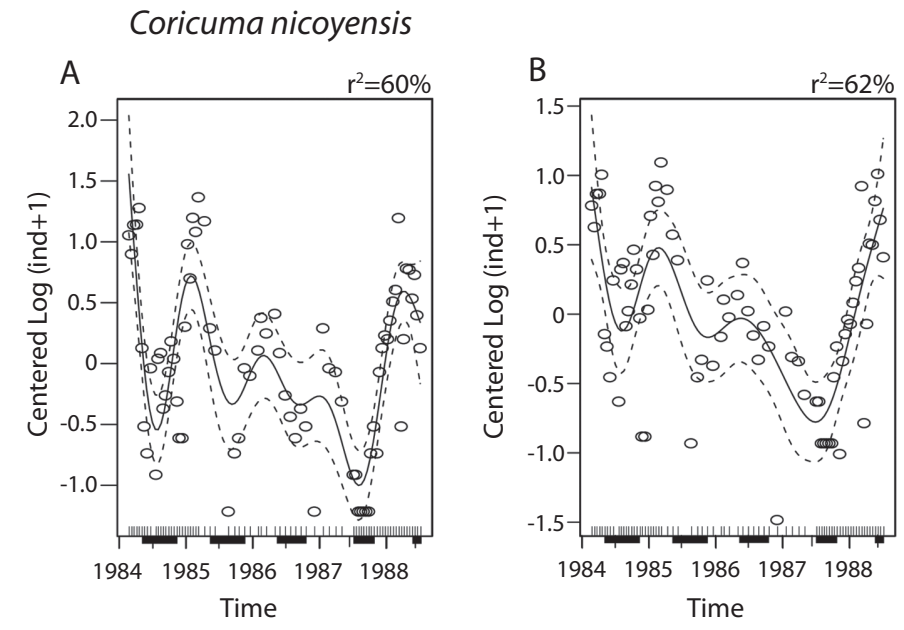

C

Temporal trends

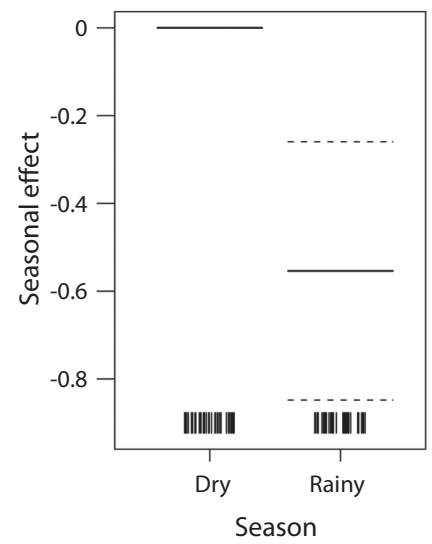

D

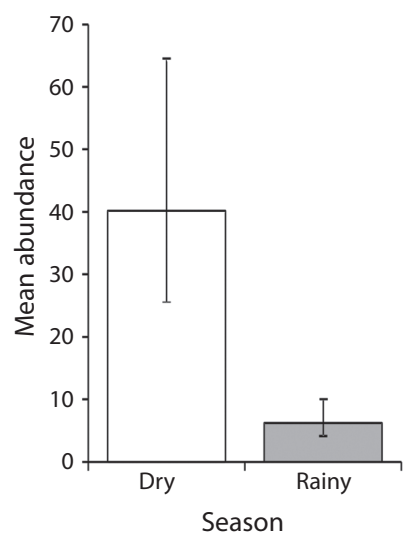

Fig. 6. A, B, C: Outputs of the Generalized Additive Models (GAM) for the abundance of the cumacean Coricuma nicoyensis. A: Without the seasonal effect in the model. B: With the seasonal effect added. Solid line is the fitted value for the model. Broken lines are the $95 \%$ confidence limits. Deviances explained were 60 and $62 \%$, respectively. Dark bars at the bottom = rainy seasons. D: Seasonal (dry vs rainy) mean abundance of C. nicoyensis for the 1984-1988 sampling period.

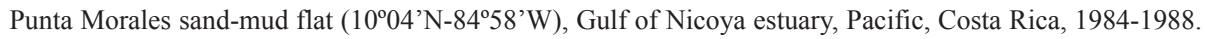

red tide have been documented for a subtropical embayment (Tampa Bay, $28^{\circ}$ N, U.S.A) by Simon \& Dauer (1977), where crustaceans like cumaceans, amphipods, and the crab Pinnixa sayana collected before the red tide were not found at the site one month after the bloom. The direct impact of a toxic dinoflagellate bloon on the benthos (Wellington Harbour, $41^{\circ} \mathrm{S}$, New Zealand) has been documented by Wear \& Gardner (2001) where small burrowing invertebrates were affected most. Mass mortalities of fish were observed in the inner Gulf of Nicoya also in 1985, with red tides suggested as a possible cause (Szelistowski \& Garita 1989). Moreover, eggs and larvae of anchovies were low in abundance during the 1985 red 


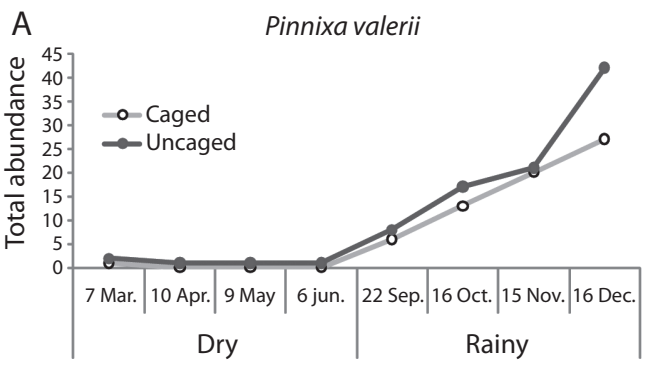

B

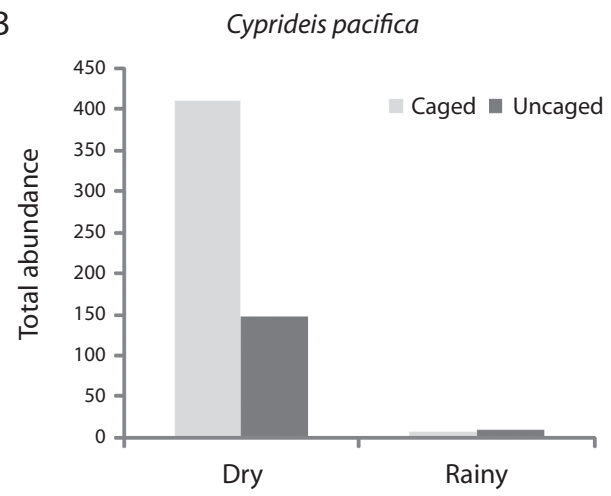

C

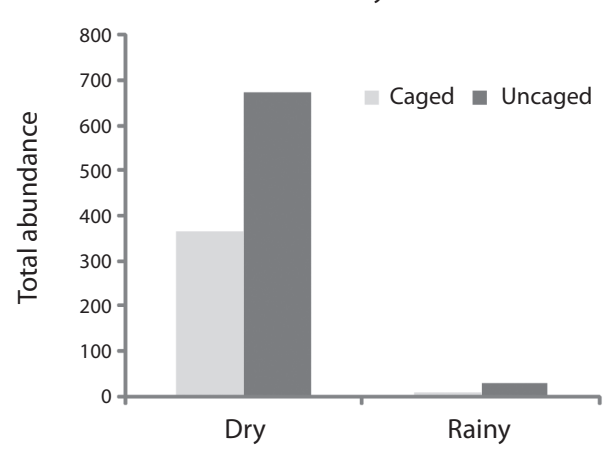

Fig. 7. Total abundances of $\mathbf{A}$ : The crab P. valerii, in all cores taken inside (caged) and outside (uncaged) plots during the dry and rainy season sets of experiments. Note the higher abundance of the crab during the rainy season. B,C: Total abundances inside and outside cages during the dry and rainy seasons for the ostracod C. pacifica and the cumacean $C$. nicoyensis. Note the lower abundances of both species during the rainy season. tides at the Punta Morales creek North of the study site (Fig. 1) and offshore (Ramírez \& Szelistowski 1989).

Pollution is often blamed worldwide as the cause of population fluctuations and extinctions and may also be a potential source of community change. An evaluation of trace metal concentrations in sediments and invertebrates (including several crustaceans) was conducted in the Gulf of Nicoya in 1981-82, with one station in front of Punta Morales. Trace metal concentrations in the Gulf were found comparable to those of non-industrialized estuaries (Dean et al. 1986) and no evidence of any influx of pollutants was known to occur in this time period.

One other potential environmental variation that could have effected the crustacean populations in the Gulf of Nicoya at this time is changes in the sediments. According to Vargas (1996) the sediments at the study site were covered at times by a thin film of pennate diatoms. Benthic diatoms produce biofilms that modify sediment characteristics and dynamics (Brouwer et al. 2005).

With the above mentioned stressors in mind, the population oscillations documented in this study are considered atypical for a seasonal (dry $v s$ rainy) estuary like the Gulf of Nicoya.

\section{The crustaceans of the uncaged sediments}

The three year survey at the tropical estuarine sand-mud flat yielded an updated list of 112 species of macroinvertebrates. Dittman (2002) compared the species richness found at four temperate tidal flats (mean: 69 species), with that at 15 tropical flats (mean: 149), including data from Vargas (1987). From this comparison it appears that tropical flats are more diverse than their temperate counterparts. Three of the tropical sites, however, had species numbers similar to the temperate flats. 
TABLE 2

Examples of differences in the number of individuals of the three top species of crustaceans found in sets $(A, B)$ of 14 cores each (17 dates). The abundances / core for the date with the highest number of individuals of each species is included at the bottom (highest number/core in bold). Punta Morales sand-mud flat $\left(10^{\circ} 04^{\prime} \mathrm{N}-84^{\circ} 58^{\prime} \mathrm{W}\right)$. Gulf of Nicoya estuary. Pacific coast of Costa Rica

\begin{tabular}{cccc} 
1984 - 1985 & P. valerii & C. pacifica & C. nicoyensis \\
Feb. 22 & A / B & A / B & A B \\
Mar. 8 & $1 / 0$ & $363 / 33$ & $185 / 46$ \\
Mar. 20 & $0 / 0$ & $221 / 59$ & $121 / 112$ \\
Apr. 5 & $1 / 0$ & $251 / 77$ & $225 / 185$ \\
Apr. 17 & $2 / 4$ & $410 / 361$ & $226 / 215$ \\
May 16 & $3 / 0$ & $607 / 325$ & $310 / 95$ \\
Jun. 19 & $2 / 0$ & $131 / 78$ & $4 / 1$ \\
Aug. 28 & $2 / 0$ & $5 / 9$ & $14 / 13$ \\
Sep. 10 & $1 / 1$ & $25 / 1$ & $6 / 6$ \\
Sep. 27 & $4 / 2$ & $3 / 1$ & $6 / 6$ \\
Oct. 10 & $14 / 2$ & $7 / 10$ & $13 / 2$ \\
Oct. 26 & $6 / 4$ & $21 / 5$ & $24 / 4$ \\
Nov. 24 & $5 / 5$ & $3 / 13$ & $17 / 13$ \\
Dec. 26 & $2 / 1$ & $2 / 2$ & $4 / 2$ \\
Jan. 10 & $6 / 2$ & $8 / 5$ & $32 / 16$ \\
Jan. 24 & $5 / 3$ & $11 / 9$ & $156 / 81$ \\
Feb. 7 & $2 / 1$ & $7 / 10$ & $80 / 79$ \\
\hline
\end{tabular}

$\begin{array}{lllllllllllllllll}\text { P. valerii (Dec. 16, 1985. Fig. 1): } & 3 & 5 & 5 & \mathbf{1 4} & 0 & 2 & 0 & 3 & 3 & 3 & 2 & 2 & 0 & 0 & = & 42\end{array}$

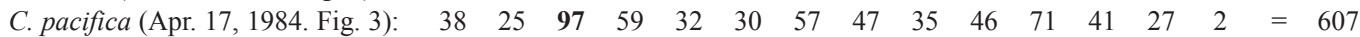

\begin{tabular}{|c|}
\hline C. nicoyensis (Mar. 7, 1985. Fig. 4): \\
\hline
\end{tabular}

Morisita's index of dispersion $\left(\chi^{2}, \mathrm{p}\right)$ : Dec. 16, 1985: 2.05 (56.05, p<0.001); Apr. 17, 1984: 1.24 (158.44, p<0.001); Mar. 7, 1985: $1.85(335.15, \mathrm{p}<0.001)$

Although comparisons of latitudinal diversity gradients are useful in ecology, the lack of a standardized sampling methodology and scarce taxonomic expertise make these comparisons difficult. These comparisons are important towards understanding how intertidal systems work at different latitudes, and therefore contribute to their sustainable use. The study by Attrill et al. (2001), based on 20 estuarine surveys (including Vargas 1996) with similar methods (500 micron mesh sieve being one of them) and environmental conditions (salinity, and mean grain size), found a significant increase towards the tropics on the species diversity (Simpson's index) of benthic estuarine invertebrates.
This study recorded 29 species $(26 \%$ of the total 112) of crustaceans at the sand-mud flat. Dittmann \& Vargas (2001) compared the taxonomic composition of the macrofauna in tidal flats in Australia and Central America and found that the percentages of crustacean species were between 10 to $40 \%$ and most of the species were represented by very low abundances or by single records (18 taxa in Table 1 have abudances below 30 individuals).

There were 17 species of decapods found in the sand-mud flat. There are about 437 species of decapods reported for the Pacific coast of Costa Rica (Vargas \& Wehrtmann 2009). The most recent (1992) trawl survey of subtidal sediments in the inner Gulf of Nicoya found 
TABLE 3

Comparison of total abundances of all crustaceans and other groups found in the uncaged and caged plots*. Top: dry season (March-June, 1985). Bottom: rainy season (September-December, 1985). Last column: significance of the Chisquare $\left(\chi^{2}\right)$ tests. Punta Morales sand-mud flat $\left(10^{\circ} 04^{\prime} \mathrm{N}-84^{\circ} 58^{\prime} \mathrm{W}\right)$, Gulf of Nicoya estuary, Pacific, Costa Rica

\begin{tabular}{lccc}
\multicolumn{1}{c}{ Number of individuals } & Uncaged & Caged & $\left(\chi^{2}, \mathrm{p}\right)$ \\
All crustaceans & 856 & 801 & 0.176 \\
Amphipods & 5 & 8 & 0.405 \\
Cumaceans & 672 & 365 & $<\mathbf{0 0 0 1}$ \\
Decapods & 20 & 13 & 0.223 \\
Mysids & 0 & 1 & 0.317 \\
Ostracods & 159 & 414 & $<\mathbf{0 . 0 0 1}$ \\
Stomatopods & 0 & 0 & 0.153 \\
All invertebrates & 1603 & 1685 & $\mathbf{< . 0 0 1}$ \\
& & & 0.02 \\
All crustaceans & 211 & 139 & $<\mathbf{0 0 0 1}$ \\
Amphipods & 12 & 3 & $\mathbf{0 . 0 5 5}$ \\
Cumaceans & 32 & 8 & 0.157 \\
Decapods & 146 & 115 & 0.465 \\
Mysids & 2 & 0 & 0.157 \\
Ostracods & 17 & 13 & $<\mathbf{0 0 1}$ \\
Stomatopods & 2 & 0 & 1414 \\
All invertebrates & 1191 & & \\
\hline
\end{tabular}

* Cages were sampled after 1 (Mar. 7, Jun. 6), 2 (Apr. 10), and 3 (May. 9) months during the dry season, and also after 1 (Sep. 22, Dec. 16), 2 (Oct. 16) and 3 (Nov. 15) months during the rainy season.

about 100 species of decapods (Vargas, Jesse \& Castro 1996). The number of crustacean species listed in table 1 is within the range reported for similar habitats on the Pacific coast of Panana $\left(9^{\circ} \mathrm{N}\right)$, where 16 species were found on a sandy beach, 20 were associated to mangroves, and 78 to rocky substrates (Abele 1976). These surveys focused on the spatial distribution of the crustacean fauna. However, studies on temporal fluctuations of decapods are scarce for the Gulf of Nicoya estuary, and those available focused mainly on subtidal species of commercial importance, like penaeid shrimps and the portunid crab Callinectes arcuatus (see Dittel et al. 1985). The study by DíazFergusson \& Vargas-Zamora (2001) described the abundance of the intertidal porcellanid crab Petrolisthes armatus at the rocky outcrops bordering the sand-mud flat study site. No seasonal trends were detected during the one year study. But recent research on this species at Punta Morales indicates high reproductive plasticity (Wehrtmann et al. 2011).

The abundance of crab larvae was evaluated by Dittel \& Epifanio (1990) at the Punta Morales tidal creek North of the study site. They found that larval crustacean species richness was higher than in temperate estuaries and that individual taxa showed marked seasonality, athough reproduction occurred throughout the year. Crab larvae mainly of the genera $U c a$, Pinnixa, Pinnotheres, Petrolisthes, and Callinectes, occurred in the plankton samples. Uca larvae, as well as those from several other decapod species, use floating mangrove leaves as a transport mechanism at the Punta Morales tidal creek (Wehrtmann \& Dittel 1990). Mangrove (Rhizophora mangle, Avicenia germinans) roots provide the substrate for interactions among other Punta Morales crustaceans, like 
the boring isopod Sphaeroma peruvianum, barnacles, and the hermit crab Clibanarius panamensis (Perry 1988).

The survey by de Goeij et al. (2003) on a tropical intertidal flat in Australia $\left(18^{\circ} \mathrm{S}\right)$ provides examples of the diversity of population fluctuation patterns in core samples $\left(10.3 \mathrm{~cm}^{2}\right)$ collected monthly over a period of 72 months (1996-2001). Excluding the polychaetes (not identified in the report), a total of 139 taxa were found. The crustaceans were represented by 28 species, a figure similar to the 26 species from the Gulf of Nicoya site. The most common Australian crabs (Macrophthalmus spp., 873 individuals) had population oscillations over the study period, with a maximun in 1998 and declining numbers afterwards. They found scarce evidence in support of repeated annual population cycles.

Abundances (14 cores) of the pinnotherid crab P. valerii, the ostracod C. pacifica, and the cumacean $C$. nicoyensis found at monthly intervals (37 dates, Feb. 1984-Feb. 1987) were illustrated by Vargas (1989a). The abundances of these three species found at semi-monthly intervals during the first year (25 dates), and at monthly intervals afterwards were included in Figs. 2, 3 and 4, respectively. The three year survey of the sand-mud flat in the Gulf of Nicoya yielded the longest data set yet available for these three species of tropical estuarine crustaceans. There has been no further research on these crustaceans.

The crab P. valerii was described by Rathbun (1931) from specimens collected in the Gulf of Nicoya. A grab survey conducted in 1980 yielded 16 species of decapods, of which $P$. valerii was collected at six stations ranging in depth from 9 to $24 \mathrm{~m}$ and silt+clay from 36 to $87 \%$ (Vargas et al. 1985).

The ostracod C. pacifica was described by Hartmann $(1957 \mathrm{a}, \mathrm{b})$ from estuarine habitats of El Salvador $\left(13^{\circ} \mathrm{N}\right)$, where he reported 21 other ostracod species. C. pacifica was found on sandy sediments containing a mixture of silt+clay and detritus, and at salinities above $17 \%$, within a temperature range of 25 to $29^{\circ} \mathrm{C}$. This species was not found there on relatively muddier substrates. The maximum number of $C$. pacifica collected at a station (no reference to type of sampling gear) by Hartmann (1957b) was 35 individuals. Swain \& Gilby (1967) studied the ostracod fauna of Corinto bay $\left(12^{\circ} \mathrm{N}\right)$ on the Pacific coast of Nicaragua and were able to identify 37 species. Cyprideis mexicana was the only one for the genus and was collected from a sandy silty-clay bottom and 36\%o water salinity. Although other species of ostracods have been reported from the Gulf of Nicoya by Maurer \& Vargas (1984), none was identified as $C$. pacifica nor this species has been reported again from Costa Rica since 1989. From these reports it appears that the ostracod fauna of the Punta Morales site is not as species rich as that found on similar estuarine environments further North. Moreover, Vargas et al. (1985) found only two species of ostracods in a grab survey at 42 subtidal stations in the Gulf of Nicoya in 1980. However, the survey by de Goeij et al. (2003) in Australian $\left(18^{\circ} \mathrm{S}\right)$ intertidal flats also collected three species of ostracods, none identified to species and with total abundances of 1071,125 and 87 individuals, respectively, over the study period.

The abundance pattern of C. pacifica over the study period characterized a declining population. The four year (1968-72) survey conducted by Heip (1976a) in a coastal dutch pond focused on the population dynamics of Cyprideis torosa, a brackish water, euryhaline, eurithermic, detritus feeder ostracod also found in other temperate latitude sites. As it occurred with $C$. pacifica the population of C. torosa had exponential bursts of abundance, followed by exponential declines. Yearly summer population peaks coincided with high water temperatures. In spite of these oscillations, the population maintained relatively high abundances during the four year period.

Two species of cumaceans were collected by coring at the sand-mud flat in the Gulf of Nicoya, one of them yet unidentified. The grab survey at 42 subtidal stations in the Gulf yielded only one species (Diastylis sp.) at a station near the Punta Morales port (Vargas et al. 1985). The total number of cumacean 
species identified for the Pacific and Caribbean coasts of Costa Rica is about 25, with several species requiring further taxonomic work. Coricuma nicoyensis was described by Watling \& Breedy (1998) from type material collected during the three year survey. The systematics of the Cumacea has been reviewed by Haye (2002) and the genus Coricuma remains as mono-specific. C. nicoyensis is considered endemic to the Gulf of Nicoya (Foster et al. 2009). The low diversity of cumaceans is surprising for a tropical site when compared, for instance, with the 22 species found in front of the port city of Barcelona $\left(41^{\circ} \mathrm{N}\right)$ in the Mediterranean (Corbera \& Cardell 1995). However, these 22 cumaceans were found in a wider area of bottom sediments differing in grain size and organic matter content. One of their shallower $(5-13 \mathrm{~m})$ sites yielded seven species and had mean concentrations of organic matter and silt+clay of 0.6 and $1.6 \%$, respectively. At a deeper site, there was also seven species found at concentrations of 1.3 and $35.7 \%$, respectively. The Punta Morales sand-mud site had, according to Vargas (1987), mean concentrations of $2 \%$ organic matter and $32 \%$ silt+clay. The cumacean Iphinoe rhodanienses was found by Corbera \& Cardell (1995) associated with higher (mean: $4.7 \%$ ) values of organic matter, and higher densities (up to $612 \mathrm{ind} . / \mathrm{m}^{2}$ ) were found near sludge discharge points. Seven species of cumaceans were also reported from a littoral survey in Japan, with half of them represented by less than 10 individuals. Bodotria similis presented spatial and temporal fluctuations in abundance, with a maximum of about 50 ind.$/ 225 \mathrm{~cm}^{2}$ at a littoral station, and 359 ind.$/ 400 \mathrm{~cm}^{2}$ at a sublittoral station (Yoda \& Aoki 2002). These densities were comparable with those found for $C$. nicoyensis at the sand-mud flat in Punta Morales, where a peak of $380 \mathrm{ind} . / 250 \mathrm{~cm}^{2}$ was found in 14 cores on April 17, 1984. The abundances included here are the highest reported so far for a tropical cumacean. However, there were no major sources of organic pollution near the study site. A low number of cumacean species in estuarine systems appears to be the rule rather than the exception. For instance, in a grab survey of Mobile Bay $\left(30^{\circ} \mathrm{N}\right)$, a shallow estuary with an area $\left(980 \mathrm{~km}^{2}\right)$ similar to that of the Gulf of Nicoya $\left(1500 \mathrm{~km}^{2}\right)$, yielded only five species of which Oxyurostylis smithi was the most abundant $(75 \%$ of a total of 1789). This species had seasonal peaks of abundance correlated with higher concentrations of salinity and dissolved oxygen (Modlin \& Dardeau 1987). The marked abundance oscillation of $C$. nicoyensis during the period 1984-85 prompted Vargas (1989b) to call this a seasonal species, but the pattern was not as clear afterwards, particularly after the 1985 red tides. However, pooled abundances during the dry seasons were higher than those from the rainy seasons. Repeated seasonality of cumaceans has been reported for Diastylis rathkei in Northern Germany $\left(54^{\circ} \mathrm{N}\right)$, with peaks during the warmer months (Rachor et al. 1982). However, more reports from tropical sites are lacking. The four year survey by de Goeij et al. (2003) of an Australian mud flat found only three cumacean specimens, and 56 gammaridean amphipods.

There were four morphological species of gammaridean amphipods collected during the 1984-87 survey, with a total of 180 individuals. Amphipods are among the more common micro-crustaceans in estuarine soft-bottoms worldwide, and oscillations in their abundance are sometimes related to pelagic displacement and their capacity for extended parental care (Thiel 1998). As with the ostracods and the cumaceans the study of these crustacean groups in tropical estuarine soft-bottoms has been delayed in part by the scarcity of taxonomic literature and of specialists in the groups. A survey of the literature by Foster et al. (2009) gathered about 43 records of amphipods for the Pacific and Caribbean coast of Costa Rica, with the genus Ampelisca being the most speciose for the Pacific coast. This survey does not include the report by Vargas et al. (1985), who listed 16 records of amphipods collected during the 1980 grab survey in the Gulf of Nicoya (Maurer \& Vargas 1984). Among these, 
only one was tentatively identified to the species level and the others to genera. A sandy (8\% silt+clay, $10 \mathrm{~m}$ depth) station yielded ten species of amphipods associated to dense mats of tubes of the chaetopterid polychaete, Mesochaetopterus alipes.

\section{Spatial patchiness}

The description of spatial patterns is an important aspect in ecological studies, as it provides indirect information on biological interactions. The use of a corer allows the retrieval of samples with a constant volume, thus minimizing sources of error due to variability in sample volume (Thrush 1991). Vargas (1987, 1988, 1989a) collected cores within a $400 \mathrm{~m}^{2}$ plot to minimize the scale of spatial variability and enhace the detection of temporal patterns. However, spatial heterogeneity within the $400 \mathrm{~m}^{2}$ plot was evidenced by differences in abundance for the same species in the two sets of cores taken during the first year of sampling. This indicates that patches in abundance existed at a horizontal distance of less than $28 \mathrm{~m}$ (maximun distance between two possible collection sites within the 20x20m plot). The distribution of individuals between cores was also patchy and at the scale close to that of the core area $\left(17.7 \mathrm{~cm}^{2}\right)$, as evidenced by Morisita's index for the date with most individuals per species. Cumaceans in general live buried in the top sediment layer during the day and swim (mostly males) at night (Yoda \& Aoki 2002), thus varying their spatial distributions daily. Cumaceans and ostracods are highly selective for certain combinations of sediment characterisitcs that are themselves patchy in their distribution. In addition, brood protection and the release of juveniles lead to aggregations of individuals. The aggregated distribution of the temperate ostracod Cyprideis torosa has been studied by Heip (1976b), who found that patches have a radius of about $13 \mathrm{~cm}$ and patterns vary between sexes. The study by Colby \& Fonseca (1984) on the spatial pattern (Morisita's index) of the temperate crab Uca pugilator indicates that this species appear to increase aggregation during the colder months.

\section{The crustaceans of the caged sediments}

Vargas (1996) conducted a caging experiment $\left(12 \mathrm{~mm}\right.$ mesh) in a temperate $\left(38^{\circ} \mathrm{N}\right)$ shallow coastal sandy embayment and total invertebrate abundance increased 4.5 times inside the caged plot. This type of benthic response has been common in temperate regions (Reise 1985). The deployment of wire cages of different mesh sizes and for different periods has been an affordable tool for investigating the impact of excluding certain macropredators (birds, crabs, fish) on temperate benthic communities. In addition, the experiments by Reise (1985) indicate that the effectivennes of a cage to exclude predators is usually masked by the presence of micropredators and by disturbances caused by the cage itself, like increased sedimentation and mesh fouling. Como et al. (2004) did not find an increase in density inside cages ( $3 \mathrm{~mm}$ mesh) kept for eight weeks at interidal muddy-sand flat in the Mediterranean $\left(42^{\circ} \mathrm{N}\right)$.

The application of the caging methodology to tropical sedimentary environments has been scarce to date and the few data reported indicate a varying response of the macrobenthos. For instance, Dittmann (1993) found a significant increase in meiofaunal abundance, but no increase in macrofaunal abundance in exclusions (1×2mm mesh wire) on a tidal flat in Australia $\left(19^{\circ} \mathrm{S}\right)$. The results reported by Vargas $(1988,1996)$ for this tropical $\left(10^{\circ} \mathrm{N}\right)$ site indicate that no significant change in total invertebrate abundance was detected between caged (5mm mesh) and uncaged plots (both season sets pooled), but total abundance was found significantly higher inside cages during the rainy season. In spite of these interpretation problems and the relatively short periods that the cages were in place, the results included in table 3 indicate that the cumaceans and the ostracods were responding to changes in the caged plots. Although the absense of mesh fouling and of significant changes in sedimentary characteristics (grain size, organic matter, color, topographic relief) was reported by Vargas (1988), the sediments inside the caged plots 
appeared softer when the cages were lifted for sampling.

Decapod crustaceans were low in abundance inside and outside cages during the dry season. However, their abundances increased during the rainy season. Crabs have been found by Pereira (1996) to be prey items for migratory shore birds at the a nearby sand flat, where at least 16 bird species included crabs on their diets during their wintering residence. She deployed nylon rope exclosures that prevented birds from entering to plots and found that the number of macroinvertebrates inside was significantly higher than outside. The abundances of five species of birds were significantly correlated with a decrease in crab abundance. At least 13 species of migratory and resident shore birds were reported by Vargas (1988) from the sand-mud flat. A greater number of decapods (mostlty P. valerii) were found outside cages than inside during the rainy season when birds were more common might reflect changes on recruitment than on predation.

Birds are not the only group of macropredators that might have preyed on the benthos. There are several species of fish that either disturb the sediments in search for food, or feed directly on bigger prey items. Phillips (1983) has recorded more than 60 species of fish from the site. In addition, highly mobile potential predators like the stomatopod Squilla aculeata (Dittel 1991, Vargas 2009), and the blue crab Callinectes arcuatus (Dittel et al. 1985) were also found at the site.

\section{ACKNOWLEDGMENTS}

We thank Harlan K. Dean for a review of the first draft, and two anonymous reviewers for comments on the manuscript. Sergio Aguilar prepared the figures. Cyprideis pacifica was identified by Gerd Hartmann in 1985 when the senior autor was conducting research towards his Ph.D. dissertation at the University of Rhode Island, U.S.A.

\section{RESUMEN}

La disponibilidad de grupos de datos recolectados por periodos mayores a un año es escasa para ambientes marinos tropicales. Avances en hardware y software pueden acelerar el re-análisis de grupos antiguos de datos y facilitar la descripción de oscilaciones poblacionales ocultas. Mediante el uso de literatura taxonómica y programas de cómputo recientes actualizamos y re-analizamos la información sobre diversidad de crustáceos y oscilaciones poblacionales en un grupo muestras recolectadas con barreno en una planicie arenoso-fangosa en la región media superior del estuario del Golfo de Nicoya, costa Pacífica de Costa Rica (1984-1988). Se encontró un total de 112 morfo-especies de macro-invertebrados, de las que 29 fueron crustáceos. Problemas taxonómicos, especialmente con los peracáridos, impidieron la identificación completa de un grupo de especies. Las oscilaciones en la abundancia del cangrejo Pinnixa valerii, el ostrácodo Cyprideis pacifica, y el cumáceo Coricuma nicoyensis fueron analizadas con los Modelos Generales Aditivos (GAM) del programa de cómputo $R$ de acceso libre. Los modelos evidenciaron una variedad de oscilaciones poblacionales durante el periodo de toma de muestras. Estas oscilaciones probablemente incluyen perturbaciones inducidas por factores externos, como los fuertes eventos de mareas rojas de 1985. Además, al inicio de 1984 las poblaciones podrían haber estado alteradas debido al impacto de El Niño 1982-83. Entonces, las oscilaciones observadas durante el estudio se alejan del patrón estacional (seco vs lluvioso) y son consideradas atípicas para esta planicie tropical estuarina arenoso-fangosa. La diversidad de crustáceos y las oscilaciones poblacionales fueron similares a las publicadas en la literatura mundial. Sin embargo, la abundancias del cumáceo Coricuma nicoyensis, una especie endémica, son las más altas informadas para un estuario tropical. Datos comparativos sobre planicies arenoso-fangosas en el trópico continúan siendo escasos. Los crustáceos (total vs grupos) tuvieron cambios poblacionales en respuesta a la colocación de jaulas con malla para excluir macro-depredadores durante las estaciones seca y lluviosa de 1985. Parches en el tiempo y el espacio caracterizaron a las abundancias de P. valeri, $C$. pacifica y C. nicoyenis.

Palabras clave: Crustacea, Coricuma, Cyprideis, Pinnixa, bentos, estuario, Golfo de Nicoya, Costa Rica.

\section{REFERENCES}

Abele, L.G. 1976. Comparative species composition and relative abundance of decapod crustaceans in marine habitats of Panama. Mar. Biol. 38: 263-268. 
Attrill, M.J., R. Stafford \& A.S. Rowden. 2001. Latitudinal diversity patterns in estuarine tidal flats: indications of a global cline. Ecography 24: 318-324.

Brouwer, J.F.C., K. Wolfstein, G.K. Ruddy, T.E.R. Jones \& L.J. Stal. 2005. Biogenic stabilization of intertidal sediments: the importance of extracellular polymeric substances produced by benthic diatoms. Microbial Ecol. 49: 501-512.

Corbera, J. \& M.J. Cardell. 1995. Cumaceans as indicators of eutrophication on soft-botoms. Sci. Mar. 59 (Supl.1): 63-69.

Colby, D.R. \& M.S. Fonseca. 1984. Population dynamics, spatial dispersion and somatic growth of the sand fiddler crab Uca pugilator. Mar. Ecol. Progr. Ser. 16: $269-279$.

Collie, J.S., S.J. Hall, M.J. Kaiser \& I.R. Poiner. 2000. Quantitative analysis of fishing impacts on shelf-sea benthos. J. Anim. Ecol. 69: 785-798.

Como, S., F. Rossi \& C. Lardicci. 2004. Response of deposit-feeders to exclusion of epibenthic predators in a Mediterranean intertidal flat. J. Exp. Mar. Biol. Ecol. 303: 157-171.

Dean, H.K., D. Maurer, J.A. Vargas \& C.H. Tinsman. 1986. Trace metal concentrations in sediments and invertebrates from the Gulf of Nicoya, Costa Rica. Mar. Pollut. Bull. 17: 128-130.

Díaz-Fergusson, E. \& J.A. Vargas-Zamora. 2001. Abundance of Petrolisthes armatus (Crustacea: Porcellanidae) on a tropical estuarine intertidal rocky beach, Gulf of Nicoya estuary, Costa Rica. Rev. Biol. Trop. 49 (Suppl. 2): 97-101.

Dittel, A.I., C.E. Epifanio \& J.B. Chavarría. 1985. Population biology of the portunid crab Callinectes arcuatus Ordway in the Gulf of Nicoya, Costa Rica, Central America. Est. Coastal Shelf Sci. 20: 593-602.

Dittel, A.I. \& C.E. Epifanio. 1990. Seasonal and tidal abundance of crab larvae in a tropical mangrove system, Gulf of Nicoya, Costa Rica. Mar. Ecol. Prog. Ser. 65: 25-34.

Dittel, A.I. 1991. Distribution, abundance, and sexual composition of stomatopods in the Gulf of Nicoya, Costa Rica. J. Crust. Biol. 11: 269-276.

Dittmann, S. 1993. Impact of foraging soldiercrabs (Decapoda: Mictyridae) on meiofauna in a tropical tidal flat. Rev. Biol. Trop. 41: 627-637.

Dittmann, S. \& J.A. Vargas. 2001. Tropical tidal flat benthos compared between Australia and Central America, p. 275-293. In K. Reise (ed.). Ecological comparisons of sedimentary shores. Ecological Studies Vol. 151. Springer, Berlin, Germany.

Dittmann, S. 2002. Benthic fauna in tropical tidal flats - a comparative perspective. Wetlands Ecol. Manag. 10: 189-195.
Foster, J.M., S.E. LeCroy, R.W. Heard \& R. Vargas. 2009. Gammaridean amphipods, p. 265-274. In I.S. Wehrtmann \& J. Cortés (eds.). Marine Biodiversity of Costa Rica, Central America. Springer, Dordrecht, The Netherlands.

de Goeij, P., M. Lavaleye, G.B. Pearson \& T. Piersma. 2003. Seasonal changes in the macro-zoobenthos of a tropical mud flat. Report on the MONROEB-MONitoring ROEbuck Bay benthos 1996-2001. Royal Netherlands Institure for Sea Research (NIOZ). Report 2003-4. Texel, The Netherlands. 53 p.

Glynn, P.W., J. Cortés, H. Guzmán \& R.H. Richmond. 1988. El Niño (1982-1983) associated coral mortality in relationship to sea surface temperature deviations in the tropical eastern Pacific. Proc. 6th Int. Coral Reef Symp., Australia 3: 237-243.

Hartmann, G. 1957a. Contribución al conocimiento de la región de esteros y manglares de El Salvador y su fauna de ostrácodos. Comunicaciones (Inst. Trop. Investig. Cient. Univ. El Salvador) VI (3/4): 47-120.

Hartmann, G. 1957b. Zur Kenntnis des Mangrove-EsteroGebietes von El Salvador und seiner OstracodenFauna. II. Kieler Meeresforsch. 13: 134-159.

Haye, P. 2002. Systematics of the Cumacea (Crustacea). Electronic Theses \& Dissertations 339. (http:// digitalcommons.library.umaine.edu/etd/339).

Heard, R.W., O. Breedy \& R. Vargas. 2009. Tanaidaceans, p. 245-256. In I.S. Wehrtmann \& J. Cortés (eds). Marine Biodiversity of Costa Rica, Central America, Central America. Springer, Dordrecht, The Netherlands.

Heip, C. 1976a. The life-cycle of Cyprideis torosa (Crustacea-Ostracoda). Oecologia 24: 229-245.

Heip, C. 1976b. The spatial pattern of Cyprideis torosa (Jones, 1850), (Crustacea:Ostracoda). J. Mar. Biol. Ass. U.K. 56: 179-189.

Maurer, D. \& J.A. Vargas. 1984. Diversity of soft-bottom benthos in a tropical estuary: Gulf of Nicoya, Costa Rica. Mar. Biol. 81: 97-106.

Modlin, R.F. \& M. Dardeau. 1987. Seasonal and spatial distribution of cumaceans in the Mobile Bay estuarine system, Alabama. Estuaries 10: 291-297.

Phillips, P.C. 1983. Diel and monthly variation in abundance, diversity and composition of littoral fish populations in the Gulf of Nicoya, Costa Rica. Rev. Biol. Trop. 31: 297-306.

Pereira, A. 1996. The impact of foraging by sandpipers (Scolopacidae) on populations of invertebrates in the intertidal zone of Chomes Beach, Gulf of Nicoya, Costa Rica, p. 44-51. In P. Hicklin (ed.). Shorebird ecology and conservation in the Western Hemisphere. International Wader Studies 8. Canadian Wildlife Service, Canada. 
Perry, D. 1988. Effects of associated fauna on growth and productivity in the red mangrove. Ecology 69: 1064-1075.

Petrescu, I., R.W. Heard, R. Vargas \& O. Breedy. 2009. Cumaceans, p. 237-244. In I.S. Wehrtmann \& J. Cortés (eds.). Marine Biodiversity of Costa Rica, Central America, Central America. Springer, Dordrecht, The Netherlands.

Price, W.W., R. Heard \& R. Vargas. 2009. Shallow water mysids, p. 229-236. In I.S.Wehrtmann \& J. Cortés (eds). Marine Biodiversity of Costa Rica, Central America. Springer, Dordrecht, The Netherlands.

Rachor, E., W. E. Arntz, H. Rumohr \& K.H. Mantau. 1982. Seasonal and long term population fluctuations in Diastylis rathkei (Crustacea:Cumacea) on Kiel Bay and German Bight. Neth. J. Sea. Res. 16: 141-150.

Ramírez, A.R. \& W. Szelistowski. 1989. Spawning pattern and larval recruitment in Gulf of Nicoya anchovies (Pisces: Engraulidae). Rev. Biol. Trop. 37: 55-62.

Rathbun, M.J. 1931. A new Pinnotherid crab from Costa Rica. J. Wash. Acad. Sci. 21: 262-263.

Reise, K. 1985. Tidal flat ecology. An experimental approach to species interactions. Ecological Studies 54. Springer, Berlin, Germany. 191p.

Simon, J.L. \& D.M. Dauer. 1977. Reestablishment of a benthic community following natural defaunation, p. 139-154. In B. C. Coull (ed.). Ecology of Marine Benthos. The Belle W. Baruch Library in Marine Science $\mathrm{N}^{\mathrm{0}}$. University of South Carolina, Columbia, South Carolina, U.S.A.

Stoner, A.W., J.P. Manderson \& J.P. Pessutti. 2001. Spatially explicit analysis of estuarine habitat for juvenile winter flounder: combining generalized additive models and geographic information systems. Mar. Ecol. Prog. Ser. 213: 253-271.

Swain, F.M. \& J.M. Gilby. 1967. Recent Ostracoda from Corinto Bay, Western Nicaragua, and their relationship to some other assemblages of the Pacific coast. J. Paleontol. 41: 306-334.

Szelistowski, W. \& J. Garita. 1989. Mass mortality of sciaenid fishes in the Gulf of Nicoya, Costa Rica. Fish. Bull. U.S. 87: 363-365.

Tarazona, J., H. Salzwedel \& W. Arntz. 1988. Oscillations of macrobenthos in shallow waters of the Peruvian coast induced by El Niño 1982-83. J. Mar. Res. 46: 593-611.

Thiel, M. 1998. Population biology of Dyopedos monacanthus (Crustacea: Amphipoda) on estuarine soft-bottom: importante of extended parental care and pelagic movements. Mar. Biol. 132: 209-221.

Thrush, S.F. 1991. Spatial patterns in soft-bottom communities. Trends Ecol. Evol. 6: 75-79.

Vanagt, T., E. Beekman, M. Vincx \& S. Degraer. 2006. ENSO and sandy beach macrobenthos of the tropical Eastern Pacific: some speculations. Adv. Geosc. 6: 57-61.

Vargas, J.A., H. K. Dean, D. Maurer \& P. Orellana. 1985. Lista preliminar de invertebrados asociados a los sedimentos del Golfo de Nicoya, Costa Rica. Brenesia $24: 327-342$.

Vargas, J.A. 1987. The benthic community of an intertidal mud flat in the Gulf of Nicoya, Costa Rica. Description of the community. Rev. Biol. Trop. 35: 229-316.

Vargas, J.A. 1988. Community structure of macrobenthos and the results of macropredator exclusion on a tropical mud flat. Rev. Biol. Trop. 36: 287-308.

Vargas, J.A. 1989a. A three year survey of the macrofauna of an intertidal mud flat in the Gulf of Nicoya, Costa Rica, p. 1905-1919. In O. Magoon, M. Converse, D. Miner, L.T. Tobin \& D. Clark (eds.). Proc. 6th Symp. on Coastal and Ocean Management, Vol. 2. Amer. Soc. Civil Eng., New York, U.S.A.

Vargas, J.A. 1989b. Seasonal abundance of Coricuma nicoyensis Watling \& Breedy, 1988 (Crustacea: Cumacea) on a tropical intertidal mud flat. Rev. Biol. Trop. 37: 207-212.

Vargas, J.A. 1996. Ecological dynamics of a tropical intertidal mudflat community, p. 355-371. In K.F. Nordstrom \& C.T. Roman (eds.) Estuarine Shores: Evolution, Environments and Human Alterations. John Wiley \& Sons, London, United Kingdom.

Vargas, J.A. \& A. Mata. 2004. Where the dry forest feed the sea: The Gulf of Nicoya estuary, p. 126-135. In G.W. Frankie, A. Mata \& S.B. Vinson (eds.). Biodiversity conservation in Costa Rica: Learning the lessons in a seasonal dry forest. University of California, Berkeley, U.S.A.

Vargas, J.A. \& S. Solano. 2011. On Mellitella stokesii and Amphipholis geminata (Echinodermata), from an intertidal flat in the upper Gulf of Nicoya estuary, Pacific, Costa Rica. Rev. Biol. Trop. 59: 193-198.

Vargas-Zamora, J.A. \& J.A. Sibaja-Cordero. 2011. A molluscan assemblage from a tropical intertidal estuarine sand-mud flat, Gulf of Nicoya, Pacific, Costa Rica (1984-1987). Rev. Biol. Trop. 59: 1135-1148. 
Vargas, R., S. Jesse \& M. Castro. 1996. Checklist of crustaceans (Decapoda and Stomatopoda), collected during the Victor Hensen Costa Rica Expedition (1993/1994). Rev. Biol. Trop. 44 (Suppl. 3): 97-102.

Vargas, R. 2009. Stomatopods, p 193-197. In I.S. Wehrtmann \& J. Cortés (eds.). Marine Biodiversity of Costa Rica, Central America, Central America. Springer, Dordrecht, The Netherlands.

Vargas, R. \& I. Wehrtmann. 2009. Decapod crustaceans, p. 209-228. In I.S. Wehrtmann \& J. Cortés (eds.). Marine Biodiversity of Costa Rica, Central America, Central America. Springer, Dordrecht, The Netherlands.

Víquez R. \& P. Hargraves. 1995. Annual cycle of potentially harmful dinoflagellates in the Golfo de Nicoya, Costa Rica. Bull. Mar. Sci. 57: 467-475.

Voorhis, A., C.E. Epifanio, D. Maurer, A.I. Dittel \& J.A. Vargas. 1983. The estuarine character of the Gulf of Nicoya, an embayment on the Pacific coast of Central America. Hydrobiologia 99: 225-237.

Watling, L. \& O. Breedy. 1988. A new cumacean (Crustacea) genus from beaches of Golfo de Nicoya, Costa Rica. Rev. Biol. Trop. 36: 527-533.
Wear, R. \& J.P.A. Gardner. 2001. Biological effects of the toxic algal blooms of February and March 1998 on the benthos of Wellington Harbour, New Zealand. Mar. Ecol. Progr. Ser. 218: 63-76.

Wehrtmann, I. \& A.I. Dittel. 1990. Utilization of floating mangrove leaves as a transport mechanism of estuarine organisms, with emphasis on Decapod Crustacea. Mar. Ecol. Progr. Ser. 60: 67-73.

Wehrtmann, I.S. \& J. Cortés (eds.). 2009. Marine Biodiversity of Costa Rica, Central America. Springer, Dordrecht, The Netherlands. 538p + CD.

Wehrtmann, I.S., I. Miranda, C.A. Lizana-Moreno, P. Hernáez, V. Barrantes-Echandi \& F.L. Mantelatto. 2011. Reproductive plasticity in Petrolisthes armatus (Anomura, Porcellanidae): a comparison between a Pacific and an Atlantic population. Helgol. Mar. Res. 66: 87-96.

Wood, S.N. 2006. Generalized Additive Models: an introduction with R. Chapman \& Hall/CRC, Boca Raton, USA. 391 p.

Yoda, M. \& M. Aoki. 2002. Comparative study of the benthic and pelagic populations of Bodotria similis (Cumacea) from Izu Peninsula, Southern Japan. J. Crust. Biol. 22: 543-552. 
